\title{
CORRELATION BETWEEN PLASMA 25-HYDROXYVITAMIN D LEVEL WITH ANGIOGRAPHIC FINDINGS IN MALE STEMI PATIENTS
}

\author{
Bajarang Lal Bansal1, Trinath Kumar Mishra², Uttam Kumar Pattnaik ${ }^{3}$ \\ ${ }_{1}^{1}$ Consultant Cardiologist, Ex-Assistant Professor, FEHIRC, Dr. B.R.A.M. Hospital, PTJNMMC, Raipur. \\ 2 Professor \& HOD, Department of Cardiology, S. C. B. Medical College \& Hospital, Cuttack, Odisha. \\ 3Professor, Department of Cardiology, S. C. B. Medical College \& Hospital, Cuttack, Odisha.
}

\begin{abstract}
BACKGROUND
ABSTRACT

Around $25 \%$ of deaths among Indians are attributable to CAD. Mortality from CAD in India has increased by $103 \%$ in males and $90 \%$ in females from 1985 to $2015 .{ }^{1}$ The prevalence of CAD in urban India is about double the rate of rural India and about 4-fold higher than in the USA. ${ }^{2}$ Vitamin D deficiency (VDD) has been associated with CVD risk factors such as hypertension ${ }^{3,4}$ and diabetes mellitus with markers of subclinical atherosclerosis such as intima-media thickness and coronary calcification as well as cardiovascular events such as myocardial infarction and stroke as well as CHF. ${ }^{5}$
\end{abstract}

Aims and Objectives of this study were to evaluate the 25-OH-D status in male patients with STEMI and to know the correlation between the 25-OH-D level and severity of angiography findings.

\section{MATERIALS AND METHODS}

Total 177 patients taken as per the inclusion and exclusion criteria mentioned below. We had taken 120 patients in our study group out of which 17 did not agree for angiographic interventions and 20 patients were detected to be having newly diagnosed case of type 2 DM, Hypertension, Alcoholic liver disease, smoking, etc. So they were excluded from the study. 83 patients were in study group. 57 patients were in control group. This study is a case control study. Approval from ethical committee was taken.

\section{RESULTS}

Mean age of presentation in the study group is 50.73 yrs. \pm 11.73 yrs., range being 24 to 74 yrs.as compared to the mean age group of 49.44 yrs. \pm 13.2 yrs., range being $24-74$ yrs. ( $p$ value $>0.05$ ). Distribution patterns of angiographic findings in the study group are as described above i.e. 18 patients (21.7\%) were having single vessel disease, 30 patients $(36.1 \%)$ were having double vessel diseases and majority of the patients(35 patients) were having triple vessel diseases group i.e. $42.2 \%$. Mean 25-OH-D level found in the TVD group was $9.66 \pm 3.60 \mathrm{ng} / \mathrm{mL}$ as compared to the SVD group where the level was $21.62 \pm 2.34 \mathrm{ng} / \mathrm{mL}$, i.e. significantly lower.one way ANOVA test was applied, $\mathrm{f}$ value found to be 103.59, $\mathrm{p}$ value<0.0001). Mean 25-OH-D level in the study group with complication was $10.72 \pm 2.77 \mathrm{ng} / \mathrm{mL}$ i.e. significantly lower as compared to the study group without complication where the mean $25-\mathrm{OH}-\mathrm{D}$ was $18.37 \pm 4.80 \mathrm{ng} / \mathrm{mL}$ ( $\mathrm{p}$ value being $<0.0001$ ). It suggests that those patients with lower $25-\mathrm{OH}-\mathrm{D}$ were having more trend towards complications like heart failure, arrhythmia, periprocedural AMI, etc.

\section{CONCLUSION}

Our findings suggested low plasma 25-OH vitamin D in the STEMI patients when compared to the level in the age matched control group; and the lower the level of plasma $25-\mathrm{OH}$ vitamin D the more severe were the incidences of severe angiography findings as described earlier specially in male patients and more were the incidence of complications. Hypovitaminosis D is another novel prognostic indicator for the severity of the CAD which can be treated aggressively to decrease the morbidity and mortality due to coronary artery disease.

\section{KEYWORDS}

Plasma 25- (OH) Vitamin D, STEMI.

HOW TO CITE THIS ARTICLE: Bansal BL, Mishra TK, Pattnaik UK. Correlation between plasma 25-hydroxyvitamin D level with angiographic findings in male STEMI patients. J. Evolution Med. Dent. Sci. 2016;5(103):7577-7586, DOI: $10.14260 /$ jemds/2016/1715

\section{BACKGROUND}

In most populations studied, the rate of CVD-related death is elevated at higher latitudes, increases during the winter months, and is lower at high altitudes due to some unknown reasons.

Financial or Other, Competing Interest: None.

Submission 04-12-2016, Peer Review 17-12-2016,

Acceptance 19-12-2016, Published 26-12-2016.

Corresponding Author:

Dr. Bajarang Lal Bansal,

G-13, Maruti Residency,

Amlihdih, Raipur.

E-mail: blbansal2002@gmail.com

DOI: $10.14260 /$ jemds $/ 2016 / 1715$
The vitamin D axis affects vascular SMC proliferation, inflammation, vascular calcification, the renin-angiotensin system (RAS), and blood pressure, all of which affect risk of CVD i.e. myocardial infarction (MI), a potentially life threatening manifestation. Vitamin D also impacts endothelial cell function, regulating endothelial cell-dependent vasodilation. ${ }^{6-8}$

Around $25 \%$ of deaths among Indians are attributable to CAD. Mortality from CAD in India has increased by 103\% in males and $90 \%$ in females from 1985 to 2015 . The prevalence of CAD in urban India is about double the rate of rural India and about 4-fold higher than in the USA. ${ }^{9}$

Vitamin D deficiency (VDD) has been associated with CVD risk factors such as hypertension ${ }^{10,11}$ and diabetes mellitus, with markers of subclinical atherosclerosis ${ }^{12}$ such as intima- 
media thickness and coronary calcification as well as with cardiovascular events such as myocardial infarction and stroke as well as CHF. Low vitamin D levels have been associated with increased CVS morbidity \& mortality in general population 1 \& in type $1 \& 2$ diabetes mellitus. ${ }^{13}$

Although VDD is frequently unrecognised clinically, laboratory measurement is easy to perform and treatment of VDD is relatively well tolerated and inexpensive. ${ }^{14}$

Because of its long half-life, 25- OH-D measurements are clinically useful for assessing vitamin D status in patients ${ }^{15}$ as it reflects the state of dietary supplement and endogenous production of vitamin D in the body. The level of 25-OH-D level also does not change like acute phase reactants in AMI, thus suggesting the constant level throughout the disease. Low level of vitamin $\mathrm{D}$ has been correlated with severity of CAD and the aim of this study is to correlate between the severity of angiographic findings with vitamin $\mathrm{D}$ level so that hypovitaminosis $\mathrm{D}$ can also be a marker of bad prognosis in coronary artery disease.

Despite these suggestive ecologic data and plausible mechanisms, data directly linking vitamin D levels to risk of MI are sparse. Because hypovitaminosis D is prevalent and easily correctable, establishing the relationship between vitamin $\mathrm{D}$ and risk of MI is important from treatment point of view.

\section{Epidemiology}

\section{Epidemiology in World}

Annual death rates in males and females caused by CVD are $37 \%$ and $41 \%$ respectively in the USA and $40 \%$ and $52 \%$, respectively in Germany. In 1990, 63\% of world mortality due to CVD were contributed by the developing countries ${ }^{16}$ which may rise to $76 \%$ of an estimated 25 million deaths in 2020 in economically developing countries. ${ }^{17}$

The French paradox indicates that mortality from CVD is relatively low in France despite a high intake of saturated fatty acids. ${ }^{18}$ The other paradoxes like The Italian paradox, ${ }^{19}$ The Northern Ireland paradox, ${ }^{20}$ The Albanian paradox ${ }^{21}$ indicate that some other cause might be contributing apart from the common aetiological risk factors for CVS disease. The Indian paradox indicates that CVD mortality rate in urban populations is higher compared with rural populations despite a very low fat intake.22 Hypertension is also less common or less severe at higher altitudes. ${ }^{23}$ Controlled clinical studies have demonstrated that regular exposure to UVB radiation but not to UVA radiation increases circulating 25(OH)D above a level of $100 \mathrm{nmol} / \mathrm{L}$ and also significantly reduces blood pressure by approximately $6 \mathrm{mmHg}$ in hypertensive patients within an intervention period of 6 weeks 18 .

In Scotland, IHD mortality rates showed a nadir in summer, approximately $30 \%$ lower compared with winter ${ }^{24}$ \& winter peak and a summer nadir in male and female IHD deaths. ${ }^{25}$ The prevalence of risk factors for CVD and also of disease rates is higher in urban than in rural communities in India $26,27 \&$ the same is true in African countries. ${ }^{28}$ In fact a South American study supported the same findings. ${ }^{6}$

\section{Epidemiology in India}

In view of being a tropical country, it was a disbelief that VDD is uncommon in India. ${ }^{29}$ However, from the data available, VDD is very common in India in all the age groups and both sexes across the country. ${ }^{30-32}$ Vit $\mathrm{D}$ is a fat soluble vitamin and its synthesis in the body is dependent on multiple factors like latitude, atmospheric pollution, clothing, skin pigmentation and duration and time of exposure to sunlight. There is widespread prevalence of varying degrees $(50-90 \%)$ of Vit D deficiency with low dietary calcium intake in Indian population according to various studies published earlier. ${ }^{30}$

CV Harinarayan et al have studied 25(OH)D and BMD in women of reproductive (WR) age group and postmenopausal women (PMW) in South India. 33 They have reported VDD in $76 \%$ in WR, $70 \%$ in PMW, insufficiency in $16.5 \%$ in WR and $23 \%$ in PMW. VDD is considered to be present when serum 25(OH)D levels are <20 ng/mL; insufficiency between 20-30 $\mathrm{ng} / \mathrm{mL}$ and sufficient when $>30 \mathrm{ng} / \mathrm{mL}^{34-36}$ In this study, there is VDD which coexists with low BMD.

\section{Vitamin D Physiology and Pathology}

There are 2 major forms of vitamin D, vitamin D2 (ergocalciferol) and vitamin D3 (cholecalciferol). Vitamin D2 is found in plants and can be consumed in fortified foods or as a supplement. Vitamin D3 is obtained from either dietary sources or through conversion of 7-dehydrocholesterol in the skin upon exposure to UVB radiation 1,4. Dietary sources of vitamin D are limited to fatty fish (wild or farm salmon, mackerel, tuna fish, sardines, and cod liver oil) and products fortified with vitamin D- depending on the country, these may include dairy products, cereals, margarine, flour, and orange juice. 37,38

Both vitamin D3 obtained from exposure to the sun and from dietary sources are hydroxylated in the liver to 25hydroxyvitamin D (25[OH]D), which is then converted to the active form of vitamin D, 1,25-dihydroxyvitamin D $(1,25[\mathrm{OH}] 2 \mathrm{D})$ by 1 -alpha-hydroxylase in the kidney. ${ }^{13,39,40}$ Though vitamin $\mathrm{D}$ is known as vitamin but basically it is a hormone with wide effects on body. ${ }^{41}$ Level of 25(OH)D is the marker that is more clinically relevant for VDD. ${ }^{37}$ Circulating hormone 1,25(OH)2D works at cellular level by affecting the genetic function and altering the protein synthesis which directly or indirectly regulates numerous genes at various organs.

\section{Definition of VDD}

VDD, a common problem in the USA and worldwide 13,39 is defined as a level $75 \mathrm{nmol} / \mathrm{L}(30 \mathrm{ng} / \mathrm{mL}$ ) approximately. 42 Potential cutpoints for defining vitamin D status are listed in Table 13, including the IOM's definitions of risk of deficiency, risk of inadequacy, adequacy, and risk of concern (Including the fact that there may be a "U-shaped" relationship where very high levels may be detrimental. ${ }^{43}$ In the United States, the level of $25(\mathrm{OH}) \mathrm{D}$ taken as low is $25 \mathrm{nmol} / \mathrm{L}(10 \mathrm{ng} / \mathrm{mL}){ }^{44}$ Indian definition of VDD has also been analysed as described below, 25(OH)D levels by RIA and PTH by IRMA were measured (made by BioSource Europe SA, Belgium) and its intensity categorised into three levels. 45

- $\quad$ Mild deficiency- $15 \mathrm{ng} / \mathrm{mL} \leq 25(\mathrm{OH}) \mathrm{D}<20 \mathrm{ng} / \mathrm{mL}$

- Moderate deficiency- $8 \mathrm{ng} / \mathrm{mL} \leq 25(\mathrm{OH}) \mathrm{D}<15 \mathrm{ng} / \mathrm{mL}$.

- $\quad$ Severe deficiency- $25(\mathrm{OH}) \mathrm{D}<8 \mathrm{ng} / \mathrm{mL}$.

\section{Vitamin D and CV Risk Factors}

There is increasing evidence that vitamin D plays a role in determining risk for various cardiometabolic outcomes, particularly metabolic syndrome (MetS) and type 2 diabetes mellitus (T2DM), and systemic hypertension.13,39,24 
Epidemiological studies also suggest that the rate of hypertension, T2DM, and coronary heart disease (CHD) increase in proportion to increasing distance from the equator, suggesting a potential link to the vitamin D mechanism.

\section{Hypertension}

Vitamin D exerts a role in regulating the RAAS (a major contributor in CVD 1,2,10,20, and VDD predisposes to upregulation of the RAAS and hypertrophy of both SMCs and left ventricle (LVH is a known risk factor or marker of CVD).41,26,27 In humans, 1, $25(\mathrm{OH})$ 2D inhibits the RAAS and may lower blood pressure. VDD leads to hypertension as supported by Krause R et al study, ${ }^{28}$ Sugden J A et al study, 6 NHANES III study. ${ }^{46}$ However, in a recent meta-analysis of 3 cohorts, lower 25(OH)D was associated with an $80 \%$ greater risk of incident of HTN, whereas in a meta-analysis of 10 trials, supplementation with vitamin D only non-significantly reduced SBP by $2 \mathrm{mmHg}$ and did not reduce DBP. ${ }^{24}$

Vitamin D also affects mechanisms related with MetS and T2DM pathophysiology, including impaired beta-cell function and insulin resistance, potentially by directly activating vitamin $\mathrm{D}$ receptors or by indirect effects by a calcium homoeostasis regulation. ${ }^{24,47,48}$ Subsequently, this finding was confirmed by a meta-analysis of 5 observational studies in England, ${ }^{49}$ Pittas A. G et al study, ${ }^{50}$ Von Hurst P.R et al. 51

Chronic VDD causes secondary hyperparathyroidism, which may mediate severe detrimental CV effects by various mechanisms. The threshold for elevation of PTH is a $25(\mathrm{OH}) \mathrm{D}$ level $30 \mathrm{ng} / \mathrm{mL}$, with particular increases in Parathyroid levels at 25(OH)D levels $16 \mathrm{ng} / \mathrm{mL}$. Elevated levels of PTH are associated with increases in arterial pressure and myocardial contractility, which can lead to apoptosis, fibrosis, and vascular SMC hypertrophy as well as LVH 10,52 increase the risk of inflammation, as documented by elevated levels of Creactive protein and interleukin-10.41 Administration of $1,25(\mathrm{OH}) 2 \mathrm{D}$ in the setting of VDD has been shown to downregulate inflammatory biomarkers such as C-reactive protein. ${ }^{53}$ This may help to reduce the atherosclerosis. ${ }^{54-56}$

\section{Vitamin D, Cardiovascular Disease and Mortality}

In 1739 Framingham Offspring Study participants who were free of CV disease at baseline, the rate of major CV disease events was $53 \%$ to $80 \%$ higher among those with low vitamin $D$ levels, with the increased risk magnified among those with hypertension. ${ }^{57}$ In an analysis of 13,331 adults from the NHANES III study followed up for a median of 8.7 years, mortality was inversely associated with vitamin D levels, with the lowest quartile of $25(\mathrm{OH}) \mathrm{D}(\$ 17.8 \mathrm{ng} / \mathrm{mL})$ having a $26 \%$ increased mortality compared with the highest quartile. ${ }^{3}$ In a prospective study of 3,258 consecutive patients scheduled for coronary angiography, low 25(OH)D and 1,25(OH)2D levels were independently associated with all-cause and CV mortality. ${ }^{4}$

\section{Vitamin D and Congestive Heart Failure}

In a recent study in 43 men and 17 women with left ventricular ejection fraction of $40 \%$ or less, longer 6 -min. walk distance was correlated with higher 25(OH)D levels. ${ }^{58}$ The 6-min. walk distance is a frequently used test in heart failure patients to assess functional cardiac outcome. Data indicate that VDD is a causal factor of CHF and not just the result of disease-related alterations. Very low serum calcitriol levels $(<37.5$ pmol/L) have frequently been found in end-stage heart failure patients. ${ }^{59}$ In this study, patients in the highest calcitriol tertile had a hazard ratio for an event (Death or cardiac transplantation) of only $0.506 \quad(95 \%$ CI $0.334-0.767)$ compared with patients in the lowest calcitriol tertile, after adjustment for potential confounders.

\section{Vitamin D and the Vasculature}

Classical risk factors in the pathogenesis of CHD are smoking, dyslipoproteinaemia, hypertension, disturbed glucose metabolism, and proinflammatory processes.

Until recently, vascular calcification was considered to be a passive process that occurred as a nonspecific response to vascular damage without clinical significance. There is now accumulating evidence that vascular calcification is an active process. 60 Almost all angiographically atherosclerotic lesions are calcified. Vascular calcification can cause thrombosis, arterial rupture, and myocardial infarction.

\section{Vitamin D and Cardiac Events}

During the last decade, deficiency of serum concentrations of vitamin D metabolites are found to be prevalent in the general population in western countries reason being an inadequate skin exposure to solar ultraviolet $\mathrm{B}$ radiation.

In a nonrandomised prospective study in 1739 Framingham Offspring Study participants, individuals with low 25(OH)D levels ( $<37.5 \mathrm{nmol} / \mathrm{L})$ had a multivariable adjusted hazard ratio of 1.62 for incidents of cardiovascular disease such as myocardial infarction, coronary insufficiency, and heart failure compared with those with 25(OH)D levels of at least $37.5 \mathrm{nmol} / \mathrm{L} .{ }^{61}$ In the Women's Health Initiative study; however, myocardial infarction, ischaemic attack, hospitalisation rate for heart failure, and cardiovascular death could not be prevented by supplementation with $1000 \mathrm{mg}$ calcium and $10 \mathrm{mg}$ vitamin $\mathrm{D}$ daily compared with the placebo group. ${ }^{62}$ But several limitations such as the low daily vitamin D dose and the lack of measurements of serum 25(OH)D levels or of calcitriol or of both of the vitamin D arm of this study makes data interpretation difficult. In a nested case-control study among male participants of the Health Professionals Follow-up Study,63 men with low 25(OH)D levels $(37.5$ nmol/L) had a relative risk of 2.09 [95\% confidence interval (CI) 1.24-3.54] of myocardial infarction compared with those considered to be sufficient $(75 \mathrm{nmol} / \mathrm{L})$, after adjustment for various lifestyle and other risk factors. Very recently, data on all-cause and cardiovascular mortality in association with vitamin D status have been published from a prospective cohort study of 3258 consecutive male and female patients scheduled for coronary angiography. 63 During a median follow-up period of 7.7 years, 737 patients $(22.6 \%)$ died, including 463 deaths from cardiovascular causes. Multivariate-adjusted hazard ratios for patients in the lower two 25(OH)D quartiles (median, 19.0 and $33.3 \mathrm{nmol} / \mathrm{L}$ ) were higher for all-cause mortality (hazard ratio 2.08; 95\% CI 1.60 2.70; and hazard ratio $1.53,95 \%$ CI 1.17-2.01, respectively) and for cardiovascular mortality (Hazard ratio 2.22; 95\% CI 1.57-3.13; and hazard ratio 1.82 , 95\% CI 1.29-2.58, respectively) compared with patients in the highest $25(\mathrm{OH}) \mathrm{D}$ quartile (median, $71.0 \mathrm{nmol} / \mathrm{L}$ ). Similar results were obtained for patients in the lowest calcitriol quartile.

In line with this suggestion, a meta-analysis of controlled clinical trials came to the conclusion that vitamin D 
supplementation reduced total mortality in middle aged to elderly adults by $7 \%$ during a trial size-adjusted mean of 5.7 years. ${ }^{64}$

Sunlight provides the most potent source of vitamin D, with approximately 3,000 IU vitamin D3 for 5 to $10 \mathrm{~min}$. of mid-day, mid-year exposure of arms and legs for a light-skin Caucasian 4. Oral supplements of 50,000 IU of either D2 or D3 every 2 weeks. ${ }^{39,40}$ Among standard dietary sources of vitamin D, oily fish have the highest content of D3, ranging from 100 to 1,000 IU per $3.5 \mathrm{oz}$ serving, whereas orange juice or milk fortified with vitamin D contains about 100 IU per serving. ${ }^{39,40,65}$ Each 100 IU of vitamin D ingested daily produces about $1 \mathrm{ng} / \mathrm{mL}$ increase in 25(OH)D levels. ${ }^{66,67}$ Generally, oral supplementation of either D2 or D3 increases levels of vitamin D reasonably well.68

\section{Recent Reviews of Literature for Vit D \& CAD}

Serum 25(OH)D does not change after AMI and is likely to be a reliable marker of vitamin D status in patients with cardiovascular disease i.e. it does not behave like an acute phase reactant. Serum Vitamin D levels are independently associated with severity of CAD. VDD is associated with significant coronary stenoses in asymptomatic African American chronic cocaine users. Association of VDD with heart failure and sudden cardiac death noted in a large crosssectional study of patients referred for coronary angiography. ${ }^{69}$ Independent association of low serum 25hydroxyvitamin D and 1,25-dihydroxyvitamin D levels with all-cause and cardiovascular mortality. Low vitamin D levels predict stroke in patients referred to coronary angiography. ${ }^{70}$ The latest data supports the correlation of atherosclerosis and osteoporosis indicating the parallel progression of two tissue destruction processes with increased fatal and non-fatal coronary events, as well as higher fracture risk. Vitamin D inadequacy associated with low bone mineral density increases fall and fracture risk, leads to secondary hyperparathyroidism, calcifies coronary arteries and significantly increases cardiovascular disease. ${ }^{71}$

Two case-control studies and a small prospective study 40 found that individuals with low 25(OH)D levels were at higher risk for ischaemic heart disease. The strongest test of the hypothesis that vitamin D lowers MI risk as seen by UK study of 2686 men and women where the participants were randomized to receive 830 IU of vitamin D daily (administered as $100000 \mathrm{IU}$ of oral vitamin D3 every 4 months) or placebo for 5 years. The in-study 25(OH)D levels were $29.7 \mathrm{ng} / \mathrm{mL}$ in the vitamin D group and $21.4 \mathrm{ng} / \mathrm{mL}$ in the placebo group. There was a non-significant decrease in CVD incidence (RR,0.90; 95\% CI, 0.77-1.06) and CVD mortality (RR, 0.84; 95\% $\mathrm{CI}, 0.65-1.10)$ in the intervention group. Based on the present study, a difference of $8.3 \mathrm{ng} / \mathrm{mL}$ in $25(\mathrm{OH}) \mathrm{D}$ concentration would be associated with an RR of 0.92 , which is compatible with the previous results. A recent meta-analysis of total mortality as a secondary end point of RCTs with varying levels of vitamin D vs placebo controls found a statistically significant $8 \%$ reduction in risk of total mortality in individuals who had received vitamin D. Although the authors could not evaluate cause-specific mortality, the relatively immediate effect of a large enough magnitude to affect total mortality would suggest a benefit on CVD risk. The largest RCT of vitamin D (and calcium) supplementation and CVD risk was from the Women's Health Initiative, in which 282 postmenopausal women received either calcium $(1000 \mathrm{mg} / \mathrm{d})$ and vitamin D3 (cholecalciferol) $(400 \mathrm{IU} / \mathrm{d})$ or placebo. No reduction was observed in MI- or CHD-related deaths (hazard ratio, 1.04; $95 \% \mathrm{CI}, 0.92-1.18$ ). These results seem to be in contrast to the present findings, suggesting 2 possible explanations. First, despite our efforts to exclude confounding, it is possible that uncontrolled or residual confounding explained these results. Alternatively, the range of vitamin D studied was much wider in the HPFS, which allowed us to detect an association. The difference between the medians of the top and bottom categories, for which we observed an RR of approximately 2, was $23.5 \mathrm{ng} / \mathrm{mL}(35.5-12.0 \mathrm{ng} / \mathrm{mL})$, and the calculated reduction in MI risk per increment of $1 \mathrm{ng} / \mathrm{mL}$ of 25(OH)D was $2 \%$. In the Women's Health Initiative study, the effect of the treatment on 25(OH)D levels was not reported, but based on the dose and compliance, Lappe et al estimated it to be only 2 $\mathrm{ng} / \mathrm{mL} .{ }^{57}$ Based on the present data, such an increment would be expected to have only a $4 \%$ reduction in risk. To increase 25(OH)D levels from 12 to $35.5 \mathrm{ng} / \mathrm{mL}$ would require approximately 3000 IU of vitamin D daily. ${ }^{3}$ Although such intakes may seem high by current standards, increasing evidence demonstrates no toxic effects at intakes below 10000 IU/d. ${ }^{4}$ Because current sources of vitamin D provide much less (e.g. a glass of milk has approximately $100 \mathrm{IU}$ ), those who achieve high levels such as $35 \mathrm{ng} / \mathrm{mL}$ naturally do so largely through sun exposure.

\section{MATERIALS AND METHODS}

Aims and objectives of this study were to evaluate the 25- $\mathrm{OH}$ D status in the male patients with STEMI and to know the correlation between the 25-OH-D level and severity of angiography findings. Total 177 patients taken as per the inclusion and exclusion criteria mentioned below. We had taken 120 patients in our study group out of which 17 did not agree for angiographic interventions and 20 patients were detected to be having newly diagnosed case of type $2 \mathrm{DM}$, Hypertension, alcoholic liver diseases, smoking, etc. So they were excluded from the study. 87 patients were in study group. 57 patients were in control group. This study is a case control study. Approval from ethical committee was taken.

All STEMI (As diagnosed by ACC/AHA criteria) (table 12)75 male patients in Cardiology Emergency Department who are considered for invasive strategy (either primary or pharmacoinvasive strategy as defined by PCI guidelines ACC/AHA 2011) were included. Patients excluded are the following as described by USA/ NSTEACS/CSA patients, female patients with ACS, Poorly controlled DM, Dyslipidaemia, Smokers, Patients of old age more than 75 yrs., Morbidly obese patients, HIV positive individuals, chronic kidney disease, alcoholic liver diseases, patients who already received heparin or calcium or vitamin D, patients on glucocorticoid therapy or parathyroid hormone, chronic inflammatory diseases which affect the calcium level.

The cases were evaluated (ECG, echocardiography, angiography) and managed in the Department of Cardiology, S.C.B. Medical College and Hospital, Cuttack and the biochemical tests \& investigations like CBC, RFT, FBS, PPBS, CK, CKMB, TROP T, LDH, vitamin D (25-OH-D), lipid Profile,, were conducted in the Department of Biochemistry, S.C.B. Medical College and Hospital, Cuttack, The samples collected from volunteers without any clinical symptom or history of 
any coronary heart disease or any chronic debilitating illness will be taken as control.

Blood samples were collected in three 10-mL liquid EDTA blood tubes, placed on ice packs, stored in polystyrene foam containers, and returned to the blood storage department of biochemistry, and processing facility at the biochemistry department of S.C.B. Medical College, via overnight courier. Blood samples which were collected in the day time were analysed immediately. More than $95 \%$ of the samples arrived within 24 hours of collection. Plasma 25(OH)D levels were determined by means of ELISA method using vitamin D binding antibody.

Angiography findings will be categorised in the following groups as mentioned below $>50 \%$ of MLD or $>70 \%$ MLA in all coronary vessel except LEFT main coronary artery where $>50 \%$ of MLA).

1. SVD- single vessel disease.

2. DVD- double vessel disease (LAD+LCX, or LCX+ RCA or LAD +RCA proximal lesion excluded).

3. TVD group- triple vessel disease, Left main disease, Left main equivalent, Diffuse disease, Type $\mathrm{C}$ lesion.

The patients are divided into 2 groups according to complications like heart failure, arrhythmia, periprocedural AMI, contrast induced nephropathy, stent thrombosis. (Present or Absent.)

Severity of angiographic findings were analysed by the SCAI classification and angiography classification. Data so collected was entered into the MS Excel Sheet. Statistical analysis was conducted using SPSS 16 software. A p value less than 0.05 was taken to be significant. Qualitative data was analysed by using Chi- square test. Quantitative data was analysed using student's t test and one way ANOVA, as applicable.

Common causes of VDD are described in Table 11.

\section{Observations}

\begin{tabular}{|c|c|c|c|}
\hline $\begin{array}{l}\text { Age In } \\
\text { Groups }\end{array}$ & $\begin{array}{c}\text { Study Group } \\
\mathrm{N}=83\end{array}$ & $\begin{array}{c}\text { Control Group } \\
\mathrm{N}=57\end{array}$ & P Value \\
\hline Up to 30 & $2(2.4 \%)$ & $6(10.5 \%)$ & \multirow{6}{*}{$\begin{array}{c}\mathrm{p} \text { value } \\
>0.05\end{array}$} \\
\hline $31-40$ & $15(18 \%)$ & $9(15.8 \%)$ & \\
\hline $41-50$ & $24(28.9 \%)$ & $14(24.6 \%)$ & \\
\hline $51-60$ & 27 (32.5\%) & $12(21.1 \%)$ & \\
\hline $61-70$ & $9(10.8 \%)$ & $12(21.1 \%)$ & \\
\hline $71-75$ & $6(7.2 \%)$ & $4(7 \%)$ & \\
\hline \multicolumn{4}{|c|}{$\begin{array}{l}\text { Table 1. Age Distribution in Male } \\
\text { Patients of Both Groups (n=140) }\end{array}$} \\
\hline
\end{tabular}

\begin{tabular}{|c|c|c|c|}
\hline Age & $\begin{array}{c}\text { Study Group } \\
\mathbf{N = \mathbf { 8 3 }}\end{array}$ & $\begin{array}{c}\text { Control Group } \\
\mathbf{N = 5 7}\end{array}$ & \multirow{2}{*}{ P Value } \\
\hline$<50$ yrs. & $35(42.2 \%)$ & $29(50.88 \%)$ & \multirow{2}{*}{0.31} \\
\hline$\geq 50$ yrs. & $48(57.8 \%)$ & $28(49.12 \%)$ & \\
\hline \multicolumn{3}{|c|}{$\begin{array}{c}\text { Table 2. Age of the Study Group } \\
\text { and Control Group ( } \mathbf{n = 1 4 0 )}\end{array}$} \\
\hline
\end{tabular}

\begin{tabular}{|c|c|c|c|}
\hline $\begin{array}{l}\text { Mean } \\
\text { Age } \\
\text { with } \\
\text { S. D. }\end{array}$ & $\begin{array}{l}\text { Study Group } \\
\qquad \mathbf{N}=83\end{array}$ & $\begin{array}{c}\text { Control Group } \\
\quad \mathrm{N}=\mathbf{5 7}\end{array}$ & $\begin{array}{c}\text { P } \\
\text { Val } \\
\text { ue }\end{array}$ \\
\hline$<50$ yrs. & $50.73 y r s \pm 11.47 \mathrm{yrs}$ & $49.44 \mathrm{yrs} \pm 13.2 \mathrm{yrs}$ & 0.53 \\
\hline
\end{tabular}

\begin{tabular}{|c|c|c|}
\hline Sl. No. & CAG Findings & Study Group N=83 \\
\hline 1 & SVD & $18(21.7 \%)$ \\
\hline 2 & DVD & $30(36.1 \%)$ \\
\hline 3 & TVD Group & $35(42.2 \%)$ \\
\hline \multicolumn{3}{|c|}{ Table 4. Coronary Angiographic Profile } \\
of the Study Group (n= 83)
\end{tabular}

\begin{tabular}{|c|c|c|c|}
\hline $\begin{array}{l}\text { CAG } \\
\text { Group }\end{array}$ & $\begin{array}{l}\text { 25-OH-D Level } \\
\text { in } \mathrm{ng} / \mathrm{mL}\end{array}$ & $\begin{array}{l}\text { Study } \\
\text { Group }\end{array}$ & P Value \\
\hline SVD & $21.62 \pm 2.34$ & 18 & \multirow{3}{*}{$\begin{array}{c}<0.0001 \\
\text { (Highly } \\
\text { Significant) }\end{array}$} \\
\hline DVD & $14.60 \pm 2.10$ & 30 & \\
\hline $\begin{array}{l}\text { TVD } \\
\text { Group }\end{array}$ & $9.66 \pm 3.60$ & 35 & \\
\hline \multicolumn{4}{|c|}{$\begin{array}{c}\text { Table 5. 25-OH-D Level Correlation with CAG } \\
\text { Findings in Study Group }(n=83)\end{array}$} \\
\hline
\end{tabular}

\begin{tabular}{|c|c|c|c|}
\hline $\begin{array}{l}\text { Age in } \\
\text { Years }\end{array}$ & $\begin{array}{l}\text { Mean 25-0H-D } \\
\text { In Study Group } \\
\text { In } \mathrm{ng} / \mathrm{mL} \\
(\mathrm{N}=83)\end{array}$ & $\begin{array}{l}\text { Mean 25-0H-D } \\
\text { in Control Group } \\
\text { In } \mathrm{ng} / \mathrm{mL}(\mathrm{N}=57)\end{array}$ & $\begin{array}{c}P \\
\text { Value }\end{array}$ \\
\hline $\begin{array}{c}25-30 \\
\text { yrs }\end{array}$ & $14.17 \pm 4.03$ & $33.79 \pm 3.5$ & \multirow{6}{*}{$<0.0001$} \\
\hline $31-40$ & $15.04 \pm 5.1$ & $30.3 \pm 2.66$ & \\
\hline $41-50$ & $14.67 \pm 5.41$ & $33.62 \pm 4.99$ & \\
\hline $51-60$ & $13.7 \pm 4.88$ & $31.00 \pm 2.88$ & \\
\hline $61-70$ & $13.93 \pm 6.84$ & $31.57 \pm 4.67$ & \\
\hline $71-75$ & $10.8 \pm 6.97$ & $38.55 \pm 3.28$ & \\
\hline \multicolumn{4}{|c|}{$\begin{array}{c}\text { Table 6. Age Wise Distribution of 25-OH-D } \\
\text { Level in Both Groups }(n=140)\end{array}$} \\
\hline
\end{tabular}

\begin{tabular}{|c|c|c|l|}
\hline & $\begin{array}{c}\text { Complication } \\
\text { Present } \\
(\mathbf{N}=47)\end{array}$ & $\begin{array}{c}\text { Complication } \\
\text { Absent } \\
(\mathbf{N}=36)\end{array}$ & P Value \\
\cline { 1 - 3 } $\begin{array}{c}\text { Mean Vit D } \\
\text { Level } \pm \text { S.D. }\end{array}$ & $10.72 \pm 2.77$ & $18.37 \pm 4.80$ & \multirow{2}{*}{$<0.0001$} \\
\cline { 1 - 3 } $\mathrm{n}$ & $47(56.6 \%)$ & $36(43.4 \%)$ & \\
\cline { 1 - 3 } Table 7. Distribution of 25-OH-D level in the Study \\
Group with or Without Complication (n= 83)
\end{tabular}

\begin{tabular}{|c|c|c|c|}
\hline $\begin{array}{c}\text { CAG } \\
\text { Findings }\end{array}$ & N & Age in years & p value \\
\hline DVD & $14(29.8 \%)$ & $48.35 \pm 11.23$ & \multirow{2}{*}{$<0.0001$} \\
\hline TVD group & $33(70.2 \%)$ & $51.72 \pm 12.54$ & \\
\hline \multicolumn{3}{|c|}{ Table 8. Correlation of CAG Findings in the } \\
Study Groups with Complications (n = 47) \\
\hline
\end{tabular}

\begin{tabular}{|c|c|c|c|}
\hline Sl. No & 25-OH-D Quartiles & $\mathbf{N}$ & p value \\
\hline $1^{\text {st }}$ & $20.1-30.0$ & $15(18.1 \%)$ & \multirow{2}{*}{$<0.0001$} \\
\hline $2^{\text {nd }}$ & $10.1-20$ & $47(56.6 \%)$ & \\
\cline { 1 - 3 } $3^{\text {rd }}$ & $0.1-10$ & $21(25.3 \%)$ & \\
\cline { 1 - 2 } \multicolumn{2}{|c|}{$\begin{array}{c}\text { Table 9. Three Quartile Distribution of 25-OH-D \& } \\
\text { CAG Findings in the Study Group ( }(\mathbf{n}=\mathbf{8 3})\end{array}$} \\
\hline
\end{tabular}




\begin{tabular}{|c|c|c|c|c|c|c|}
\hline Sl. No. & 25-OH-D Quartiles & SVD $(N=18)$ & DVD $(n=30)$ & TVD $(n=35)$ & $\mathbf{N}$ & P Value \\
\hline $1^{\text {st }}$ & $20.1-30.0$ & 13 & 1 & 1 & 15 & \multirow{3}{*}{$<0.0001$} \\
\hline $2^{\text {nd }}$ & $10.1-20$ & 5 & 29 & 13 & 47 & \\
\hline $3^{\text {rd }}$ & $0.1-10$ & 0 & 0 & 21 & 21 & \\
\hline
\end{tabular}

- $\quad$ Ageing $39,13,36,23$

- Increased distance from the equator.

- Winter seasons.

- Darkly pigmented skin. ${ }^{72}$

- Institutionalised/housebound.

- Sunscreens and cover-up clothing.

- Air pollution.

- Smoking.

- $\quad$ Obesity73,34,35

- Physical inactivity.

- Genetic factors. ${ }^{74}$

- Malabsorption.

- Renal disease.

- Liver disease.

- Certain medications.

- Glucocorticoids.

- Antirejection medications.

- Human immunodeficiency virus medications.

- Certain antiepileptic drugs.

\section{Table 11. Major Risk Factors for Vitamin D Deficiency}

Either of the following Criteria Satisfies the Diagnosis for Acute, Evolving, or Recent AMI.

1. Typical rise and/or fall of biochemical markers of myocardial necrosis with at least one of the following.

a) Ischaemic symptoms.

b) Development of pathologic $Q$ waves in the ECG.

c) Electrocardiographic changes indicative of ischaemia (ST-segment elevation or depression).

d) Imaging evidence of new loss of viable myocardium or new regional wall motion abnormality.

2. Pathologic findings of an acute myocardial infarction.

Table 12. Revised Definition of Myocardial Infarction 75 Criteria for Acute, Evolving, or Recent AMI

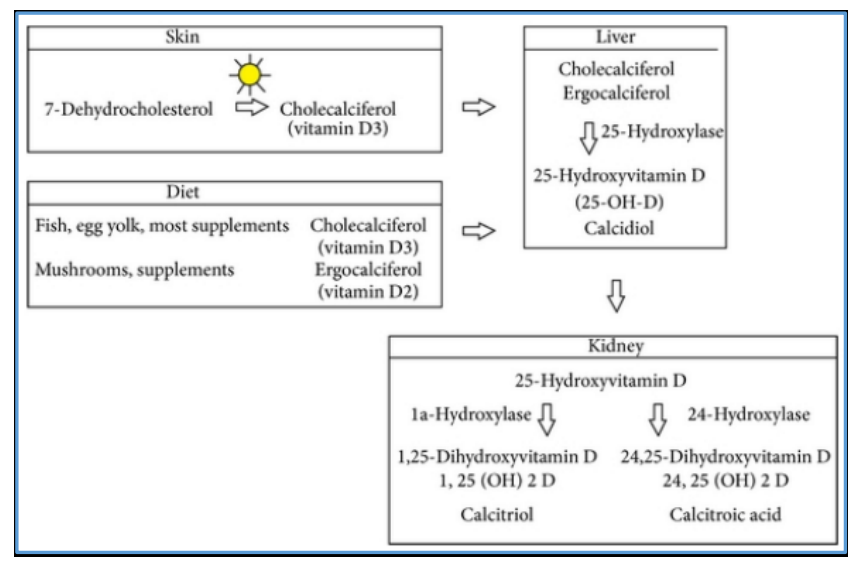

Figure 1

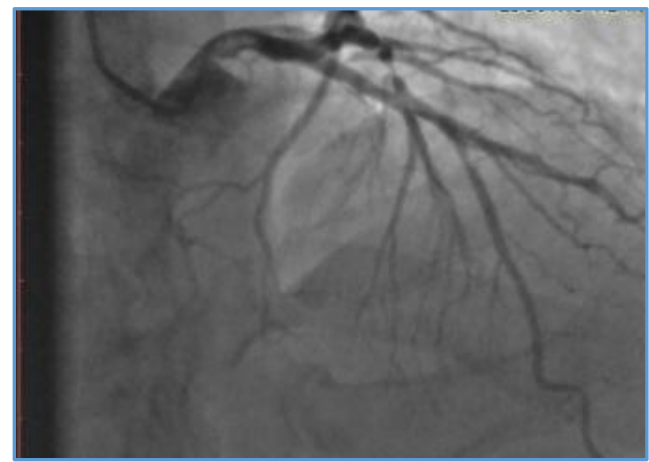

Figure 2. SVD (LESION IN LAD)

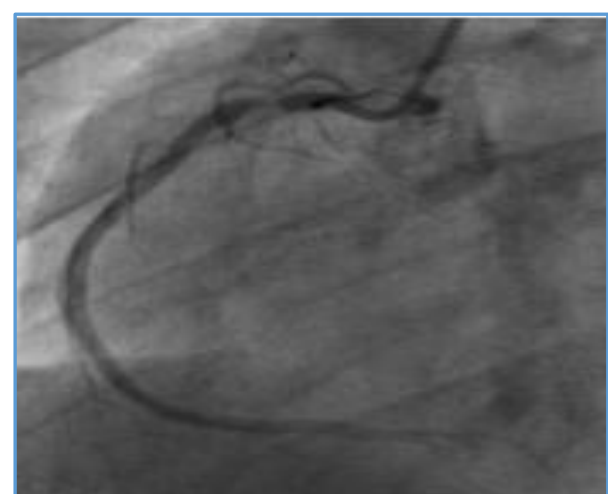

Figure 3. RCA (DVD AND TVD)
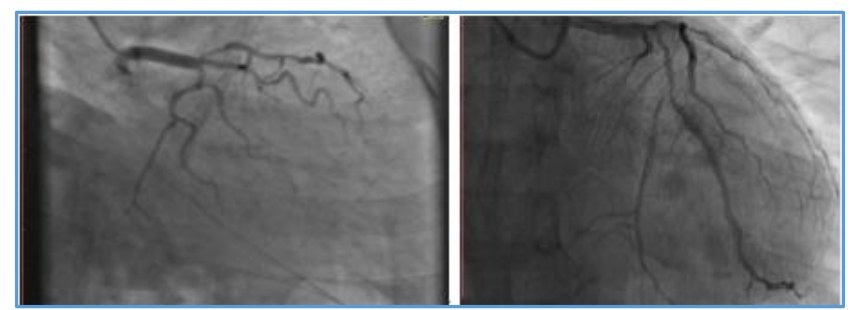

Figure 4 \& 5. Left Main Disease with LAD \& LCX Lesion

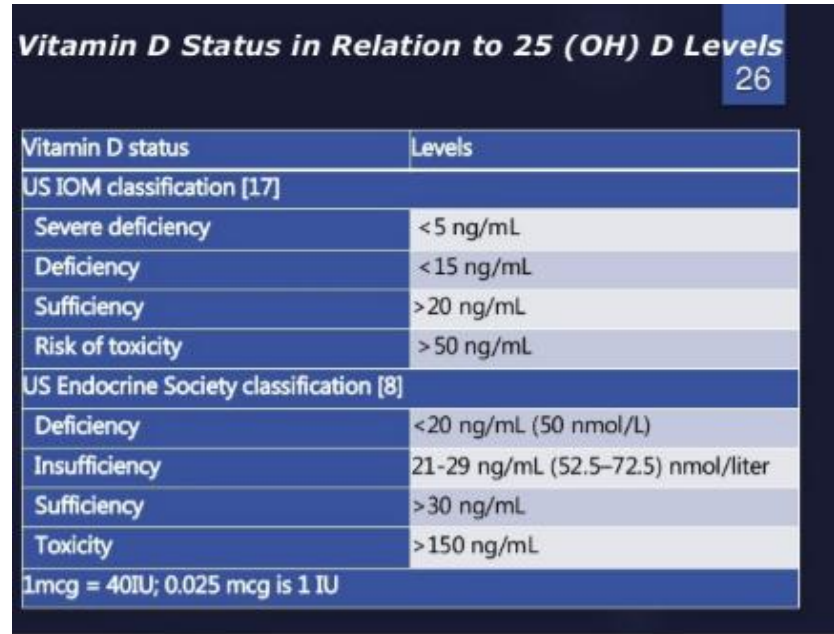

Table 13 


\section{DISCUSSION}

As depicted from the table 1, majority of patients in the study group are in the age group of $41-50$ yrs. $(28.9 \%$ vs. $24.6 \%$ in the control group) \& $51-60$ yrs. (32.5\% vs. $21.1 \%$ in the control group). ( $p$ value being more than 0.05 , i.e. statistically insignificant). When we divided the age group in 2 groups according to age of 50 years, majority of the patients in study group were above the age of 50 yrs. i.e. $57.8 \%$ as compared to $49.12 \%$ in the control group. (p value being more than 0.05 , i.e. statistically insignificant) as described in table 2 .

As depicted in table 3 , mean age of presentation in the study group is 50.73 yrs. \pm 11.73 yrs., range being 24 to 74 yrs. as compared to the mean age group of 49.44 yrs. \pm 13.2 yrs., range being 24-74 yrs. (p value being more than 0.05 ).

Distribution pattern of angiographic findings in the study group as per table 4 are as described i.e. $21.7 \%$ were having single vessel disease, $36.1 \%$ were having double vessel disease and majority of the patients were having triple vessel disease group i.e. $42.2 \%$.

Table 5 shows that mean 25-OH-D level found in the TVD group was $9.66 \pm 3.60 \mathrm{ng} / \mathrm{mL}$ as compared to the SVD group where the level was $21.62 \pm 2.34 \mathrm{ng} / \mathrm{mL}$, i.e. significantly lower. One way ANOVA test was applied, f value found to be 103.59 , $p$ value being less than 0.0001 i.e. highly significant.

Table 6 shows that average 25-OH-D level taken from the control group, prevalent in normal population was $32.47 \pm 4.35$ $\mathrm{ng} / \mathrm{mL}$ vs. $14.039 \pm 5.39 \mathrm{ng} / \mathrm{mL}$ in the study group, (p value being. $<0.0001$ ), i.e. highly significant statistically. Age wise distribution of the 25-OH-D level was also analysed so as to know the range of the normal levels of vitamin D status in each group so as to prevent any age related difference in the Vit D level as compared to the study group. When we analysed the mean level of the Vit D in the age matched study group and control group, it was observed that the mean value of $25-\mathrm{OH}-$ D was significantly lower in the study group as compared to the control group, the findings are more specific in older patients, $p$ value being $<0.0001$, i.e. highly significant. The findings were more robust in the elderly patients i.e. $13.93 \pm 6.84 \mathrm{ng} / \mathrm{mL}$ in $61-70$ yrs. group vs. $31.57 \pm 4.67 \mathrm{ng} / \mathrm{mL}$ in the control group with $\mathrm{p}$ value being $<0.0001$, i.e. highly significant, similarly in the 71-75 age group, the mean level was $10.8 \pm 6.97 \mathrm{ng} / \mathrm{mL}$ in the study group vs. mean level in the control group was $38.55 \pm 3.28 \mathrm{ng} / \mathrm{mL}$. $(\mathrm{p}<0.0001)$.

Table 7 shows that mean 25-OH-D level in the study group with complication was $10.72 \pm 2.77 \mathrm{ng} / \mathrm{mL}$ i.e. significantly lower as compared to the study group without complication where the mean vitamin D level was $18.37 \pm 4.80 \mathrm{ng} / \mathrm{mL}(\mathrm{p}$ value being $<0.0001$ ), i.e. highly significant statistically. It suggests that those patients with lower vitamin D level were having more trend towards complications like heart failure, arrhythmia, periprocedural AMI, etc.

As per table 8, also the complications like heart failure, arrhythmia or periprocedural AMI were noted in the TVD group as compared to the SVD group where not a single case of complication was noted \& fewer complications noted in DVD group which has been depicted. On analysis, it was found that the lower the vitamin D level the more severe is the complication and the more is the severity of angiographic findings as depicted in the table .(p value being $<0.00001)$.
Table 9 shows that after dividing the group of Vit D level in the 3 groups i.e. 1 st quartile -insufficient Vit D level i.e. (20-30 $\mathrm{ng} / \mathrm{mL}), 15$ (18.1\%) patients were in this group; 2nd quartile - mild to moderate insufficiency (10.1-20 ng/mL)- 47(56.6\%) patients were in this group; and in 3rd quartile i.e. severe deficiency $(<10 \mathrm{ng} / \mathrm{mL}), 21(25.3 \%)$ were in this group.

Table 10 shows that after subgroup analysis of the study group in 1st quartile $(n=15)$ it was observed that 13 out of 15 patients i.e. $86.6 \%$ were in SVD group as compared to $1(6.7 \%)$ patient in DVD group \& 1 (6.7\%) patient in TVD group. Majority of patients were having relatively milder disease. In SVD group where 18 patients were there, we found the mean $25-0 H-D$ level to be $21.62 \pm 2.34 \mathrm{ng} / \mathrm{mL}$. Amongst these SVD group, we found that 13 out of 18 patients (72.23\%) were in this quartile as compared to 5 patients $(27.77 \%)$ who were in DVD group, $p$ value being highly significant $<0.0001$. After subgroup analysis of the study group in 2 nd quartile $(n=47)$, it was observed that 5 out of 47 patients i.e. $10.64 \%$ were in SVD group as compared to 29 out of 47 patients i.e. $61.7 \%$ patients were in DVD group \& 13 out of 47 patients i.e. $27.7 \%$ patients were in TVD group. Majority of patients were having DVD followed by TVD group. In DVD group, where 31 patients were there, we found the mean 25-OH-D level to be $14.60 \pm 2.10$. Amongst DVD group, we found that 29 out of 30 patients (96.7\%) were in this quartile as compared to 1 patient $(3.3 \%)$ in 1st quartile. P value being highly significant $<0.0001$.

After subgroup analysis of the study group in $3^{\text {rd }}$ quartile $(n=21)$, it was observed that all patients i.e. $100 \%$ patients were in TVD group. In TVD group where 35 patients were there, we found the mean 25-OH-D level to be $9.66 \pm 3.60$ ng/mL. Amongst the TVD group, we found that 21 out of 35 $(60.7 \%)$ patients were in 3rd quartile, 13 out of 35 patients $(37.15 \%)$ were in 2 nd quartile as compared to 1 patient $(2.15 \%)$ in 1 st quartile. $\mathrm{P}$ value being highly significant $<0.0001$.

Findings were in favour of lower level of 25-OH D level leading to increased severity of the angiographic findings.

A Danish study examined 25 hydroxyvitamin D (25[OH]D) levels measured in 128 patients admitted to the hospital with ischaemic heart disease ( 75 with angina pectoris and 53 with acute MI) and 409 control subjects and found that $25(\mathrm{OH}) \mathrm{D}$ levels were significantly lower in those with angina (23.5 $\mathrm{ng} / \mathrm{mL}$ [to convert to nanomoles per litre, multiply by 2.496]) or MI (24.0 ng/mL) than in controls (28.8 ng/mL). In a New Zealand case-control study, 3 of 179 patients with MI, cases had a lower mean $25(\mathrm{OH}) \mathrm{D}$ level $(\mathrm{P}=.02)$, which was more pronounced in the winter-spring $(\mathrm{P}=.03)$ than in the summerautumn $(\mathrm{P}=.21)$. The relative risk (RR) of MI decreased across increasing quartiles of 25(OH)D (10 ng/mL: RR, 1 [reference]; 10-13 ng/mL: RR, 0.56 [95\% confidence interval $\{\mathrm{CI}\}, 0.32-$ 1.03]; $13.1-16.8 \mathrm{ng} / \mathrm{mL}: \mathrm{RR}, 0.33$ [95\% CI, 0.17-0.64]; and 16.8 ng/mL: RR, 0.30 [95\% CI, 0.150.61]). Multivariate analyses of major CVD risk factors did not appreciably alter the results. A small, nested, case-control study of MI based in the Tromso Heart Study (northern Norway) with only 30 cases and 60 matched controls found a slightly non-significant lower $25(\mathrm{OH}) \mathrm{D}$ level in cases $(23.6 \mathrm{ng} / \mathrm{mL})$ compared with controls $(25.4 \mathrm{ng} / \mathrm{mL})$. 


\section{CONCLUSION}

The main finding of the study which was in favour of the above studies' findings was that-

1. The level of vitamin D was low in the patients of coronary artery disease (established cases) when compared to the vitamin $\mathrm{D}$ level in the age matched control group.

2. The lower the level of vitamin $D$, the more severe was the incidence of severe angiography findings as described earlier and more is the incidence of complications.

Hypovitaminosis D is another novel prognostic indicator for the severity of the CAD.

\author{
Abbreviations \\ AMI- Acute myocardial infarction \\ 25(OH)D- 25-hydroxyvitamin D \\ 1,25(OH)2D-1,25 Dihydroxyvitamin D \\ CHD- Coronary Heart Disease \\ CAD- Coronary Artery Disease \\ CKD- Chronic Kidney Disease \\ CRP- C-reactive Protein \\ CV- Cardiovascular \\ IOM- Institute of Medicine \\ MetS- Metabolic Syndrome \\ PTH- Parathyroid Hormone \\ RAAS- Renin Angiotensin Aldosterone System \\ T2DM- Type 2 Diabetes Mellitus \\ UVB- Ultraviolet B \\ VDD- Vitamin D Deficiency
}

\section{REFERENCES}

1. Jorde R, Sneve M, Figenschau Y, et al. Effects of vitamin D supplementation on symptoms of depression in overweight and obese subjects: randomized double blind trial. J Intern Med 2008;264(6):599-609.

2. Hoogendijk WJ, Lips P, Dik MG, et al. Depression is associated with decreased 25-hydroxyvitamin D and increased parathyroid hormone levels in older adults. Arch Gen Psychiatry 2008:65(5):508-12.

3. Melamed ML, Michos ED, Post W, et al. 25-hydroxyvitamin D levels and the risk of mortality in the general population. Arch Intern Med 2008;168(15):1629-37.

4. Dobnig H, Pilz S, Scharnagel $\mathrm{H}$, et al. Independent association of low serum 25-hydroxyvitamin D and 1,25dihydroxyvitamin $d$ levels with all-cause and cardiovascular mortality. Arch Intern Med 2008;168(12):1340-9.

5. Gouni-Berthold I, Krone W, Berthold Hk. Vitamin D and cardiovascular disease. Curr Vasc Pharmacol 2009;7(3):414-22.

6. Sugden JA, Davies JI, Witham MD, et al. Vitamin D improves endothelial function in patients with type 2 diabetes mellitus and low vitamin D levels. Diabetes Med 2008;25(3):320-5.

7. Borges AC, Feres T, Vianna LM, et al. Effect of cholecalciferol treatment on the relaxant responses of spontaneously hypertensive rat arteries to acetylcholine. Hypertension 1999;34(4 Pt 2):897-901.

8. Borges AC, Feres T, Vianna LM, et al. Recovery of impaired $\mathrm{K}^{+}$channels in mesenteric arteries from spontaneously hypertensive rats by prolonged treatment with cholecalciferol. Br J Pharmacol 1999;127(3):772-8.
9. Pandage BJ, Shag VK, Gawihi MJ, et al. A study of ischemic heart disease in young patients ( $<40$ Yrs). Ind Heart Journal 1984;36:285.

10. Forman JP, Giovannucci E, Holmes MD, et al. Plasma 25hydroxyvitamin D levels and risk of incident hypertension. Hypertension 2007;49(5):1063-9.

11. Burgaz A, Byberg L, Rautiainen S, et al. Confirmed hypertension and plasma 25(Oh)D concentrations amongst elderly men. J Intern Med 2011;269(2):211-8.

12. Carrelli AL, Walker MD, Lowe H, et al. Vitamin D deficiency is associated with subclinical carotid atherosclerosis: the northern Manhattan study. Stroke 2011;42(8):2240-5.

13. Abuannai M, O'keefe JH. Vitamin D and cardiovascular health. Primary Care Cardiovasc J 2011:4:59-62.

14. Holick MF. Vitamin D deficiency. N Engl J Med 2007;357(3):266-81.

15. Deluca HF. Overview of general physiologic features and functions of vitamin D. Am J Clin Nutr 2004;80(6Suppl):1689s-96.

16. Murray CJL, Lopez AD. Mortality by cause for eight regions of the world: global burden of disease study. Lancet 1997;349(9061):1269-76.

17. Yusuf S, Reddy S, Ounpuu S, et al. Global burden of cardiovascular diseases: part I: general considerations, the epidemiologic transition, risk factors, and impact of urbanization. Circulation 2001;104(22):2746-53.

18. Renaud S, De Lorgeril M. Wine, Alcohol, Platelets, And The French Paradox For Coronary Heart Disease. Lancet 1992;339(8808):1523-6.

19. Douglas AS, Dunnigan MG, Allan TM, et al. Seasonal variation in coronary heart disease in Scotland. J Epidemiol Commun Health 1995;49:575-82.

20. Evans AE, Ruidavets JB, Mccrum E, et al. Autre pays, autres coeurs. Dietary patterns, risk factors and ischaemic heart disease in Belfast and Toulouse. Q J M 1995;88:469-77.

21. Gjonca A, Bobak M. Albanian paradox, another example of protective effect of Mediterranean lifestyle? Lancet 1997;350(9094):1815-7.

22. Singh RB, Niaz MA, Ghosh S, et al. Low fat intake and coronary artery disease in a population with higher prevalence of coronary artery disease: the Indian paradox. J Am Coll Nutr 1998;17(4):342-50.

23. Fiscella K, Franks P. Vitamin D, race, and cardiovascular mortality: findings from a national US sample. Ann Fam Med 2010;8(1):11-8.

24. Pittas AG, Chung M, Trikalinos $T$, et al. Vitamin D and cardiometabolic outcomes: a systematic review. Ann Intern Med 2010;152(5):307-14.

25. Li YC, Kong J, Wei M, et al. 1,25-Dihydroxyvitamin D(3) is a negative endocrine regulator of the renin-angiotensin system. J Clin Invest 2002;110(2):229-38.

26. Milani RV, Lavie CJ, Mehra MR, et al. Left ventricular geometry and survival in patients with normal left ventricular ejection fraction. Am J Cardiol 2006;97(7):95963.

27. Artham SM, Lavie CJ, Milani RV, et al. Clinical impact of left ventricular hypertrophy and implications for regression. Prog Cardiovasc Dis 2009;52(2):153-67.

28. Krause R, Buhring M, Hopfenmuller W, et al. Ultraviolet B and blood pressure. Lancet 1998;352(9129):709-10. 
29. Hodgkin P, Kay GH, Hine PM, et al. Vitamin-D deficiency in Asians at home and in Britain. Lancet 1973;2(7822):16771.

30. Harinarayan CV, Joshi SR. Vitamin D status in India-its implications and remedial measures. J Assoc Physicians India 2009;57:40-8.

31. Marwaha RK, Sripathy G. Vitamin D and bone mineral density of healthy school children in northern India. Indian J Med Res 2008;127(3):239-44.

32. Harinarayan CV. Prevalence of vitamin D insufficiency in postmenopausal south Indian women. Osteoporos Int 2005;16(4):397-402.

33. Harinarayan CV, Sachan A, Reddy PA, et al. Vitamin D status and bone mineral density in women of reproductive and postmenopausal age groups: a cross-sectional study from south India. J Assoc Physicians India 2011;59:698-704.

34. Cheng S, Massaro JM, Fox CS, et al. Adiposity, cardiometabolic risk, and vitamin D status: the Framingham heart study. Diabetes 2010;59(1):242-8.

35. Rajakumar K, Fernstrom JD, Holick MF, et al. Vitamin D status and response to vitamin $\mathrm{D}(3)$ in obese vs. non-obese African American children. Obesity (Silver Spring) 2008;16(1):90-5.

36. Binkley N, Novotny R, Krueger D, et al. Low vitamin D status despite abundant sun exposure. J Clin Endocrinol Metab 2007;92(6):2130-5.

37. Mosekilde L. Vitamin D requirement and setting recommendation levels: long-term perspectives. Nutr Rev 2008;66(10 Suppl 2):170-7.

38. Holden JM, Lemar LE. Assessing vitamin D contents in foods and supplements: challenges and needs. Am J Clin Nutr 2008;88(2):551S-3.

39. Lee JH, O'Keefe JH, Bell D, et al. Vitamin D deficiency: an important, common, and easily treatable cardiovascular risk factor? J Am Coll Cardiol 2008;52(24):1949-56.

40. Holick MF. Vitamin D deficiency. N Engl J Med 2007;357:266-81.

41. Zittermann A. Vitamin D and disease prevention with special reference to cardiovascular disease. Prog Biophys Mol Biol 2006;92(1):39-48.

42. Bischoff-Ferrari HA, Giovannucci E, Willett WC, et al. Estimation of optimal serum concentrations of 25hydroxyvitamin D for multiple health outcomes. Am J Clin Nutr 2006;84(1):18-28.

43. Helzlsouer KJ. Overview of the cohort consortium vitamin $\mathrm{D}$ pooling project of rarer cancers. Am J Epidemiol 2010;172(1):4-9.

44. Looker AC, Dawson-Hughes B, Calvo MS, et al. Serum 25hydroxyvitamin D status of adolescents and adults in two seasonal subpopulations from NHANES III. Bone 2002;30(5):771-7.

45. Du X, Greenfield H, Fraser DR, et al. Vitamin D deficiency and associated factors in adolescent girls in Beijing. Am J Clin Nutr 2001;74(4):494-500.

46. Scragg R, Sowers M, Bell C. Serum 25-hydroxyvitamin D, ethnicity, and blood pressure in the third national health and nutrition examination survey. Am J Hypertens 2007;20(7):713-9.

47. Pittas AG, Lau J, Hu FB, et al. The role of vitamin D and calcium in type 2 diabetes. A systematic review and metaanalysis. J Clin Endocrinol Metab 2007;92(6):2017-29.
48. Hyppönen E, Läärä E, Reunanen A, et al. Intake of vitamin D and risk of type 1 diabetes: a birth-cohort study. Lancet 2001;358(9292):1500-3.

49. Zipitis CS, Akobeng AK. Vitamin D supplementation in early childhood and risk of type 1 diabetes: a systematic review and meta-analysis. Arch Dis Child 2008;93(6):5127.

50. Pittas AG, Dawson-Hughes B, Li T, et al. Vitamin D and calcium intake in relation to type 2 diabetes in women. Diabetes Care 2006;29(3):650-6.

51. Von Hurst PR, Stonehouse W, Coad J. Vitamin D supplementation reduces insulin resistance in south asian women living in New Zealand who are insulin resistant and vitamin D deficient: a randomized, placebo-controlled trial. Br J Nutr 2010;103(4):549-55.

52. Ogard CG, Engelmann MD, Kistorp C, et al. Increased plasma N-terminal pro-B-type natriuretic peptide and markers of inflammation related to atherosclerosis in patients with primary hyperparathyroidism. Clin Endocrinol (Oxf) 2005;63(5):493-8.

53. Schleithoff SS, Zittermann A, Tenderich G, et al. Vitamin D supplementation improves cytokine profiles in patients with congestive heart failure: a double-blind, randomized, placebo-controlled trial. Am J Clin Nutr 2006;83(4):754-9.

54. Libby P, Ridker PM, Hansson GK. Inflammation in atherosclerosis: from pathophysiology to practice. J Am Coll Cardiol 2009;54(23):2129-38.

55. Lavie CJ, Milani RV, Verma A, et al. C-reactive protein and cardiovascular disease: is it ready for primetime? Am J Med Sci 2009;338(6):486-92.

56. Lavie CJ, Church TS, Milani RV, et al. Impact of physical activity, cardiorespiratory fitness, and exercise training on markers of inflammation. J Cardiopulm Rehabil Prev 2011;31(3):137-45.

57. Wang TJ, Pencina MJ, Booth SL, et al. Vitamin D deficiency and risk of cardiovascular disease. Circulation 2008;117(4):503-11.

58. Sugiuchi H, Uji Y, Okabe H, et al. Direct measurement of high-density lipoprotein cholesterol in serum polyethylene glycol-modified enzymes and sulfated alphacyclodextrin. Clin Chem 1995;41(5):717-23.

59. Thomas MK, Lloyd-Jones DM, Thadhani RI, et al. Hypovitaminosis D in medical inpatients. N Engl J Med 1998;338(12):777-83.

60. Rothman KJ, Greenland S. Case-control studies. In: Rothman Kj, Greenland S, eds. Modern epidemiology. 2nd edn. Philadelphia, Pa: Lippincott-Raven Publishers 1998:93-114.

61. Giovannucci E, Colditz G, Stampfer MJ, et al. The assessment of alcohol consumption by a simple selfadministered questionnaire. Am J Epidemiol 1991;133(8):810-7.

62. Chasan-Taber S, Rimm EB, Stampfer MJ, et al. Reproducibility and validity of a self-administered physical activity questionnaire for male health professionals. Epidemiology 1996;7(1):81-6.

63. Hollis BW, Kamerud JW, Selvaag SR, et al. Determination of vitamin D status by radioimmunoassay using $125 \mathrm{I}$ labelled tracer. Clin Chem 1993;39(3):529-33.

64. Rifai N, Iannotti E, Deangelis K, et al. Analytical and clinical performance of a homogenous enzymatic LDL-cholesterol 


\section{Jemds.com}

assay compared with the ultracentrifugation/dextran sulfate-Mg2+Method. Clin Chem 1998;44(6 Pt 1):1242-50.

65. Chen TC, Chimeh F, Lu Z, et al. Factors that influence the cutaneous synthesis and dietary sources of vitamin D. Arch Biochem Biophys 2007;460(2):213-7.

66. Vieth R. Vitamin D supplementation, 25-hydroxyvitamin D concentrations, and safety. Am J Clin Nutr 1999;69(5):84256.

67. Heaney RP, Davies KM, Chen TC, et al. Human serum 25hydroxycholecalciferol response to extended oral dosing with cholecalciferol. Am J Clin Nutr 2003;77(1):204-10.

68. Holick MF, Biancuzzo RM, Chen TC, et al. Vitamin D2 is as effective as vitamin D3 in maintaining circulating concentrations of 25-hydroxyvitamin D. J Clin Endocrinol Metab 2008;93(3):677-81.

69. Pilz S, März W, Wellnitz B, et al. Association of vitamin D deficiency with heart failure and sudden cardiac death in a large cross-sectional study of patients referred for coronary angiography. J Clin Endocrinol Metab 2008;93(10):3927-35.

\section{Original Research Article}

70. Pilz S, Dobnig H, Fischer JE, et al. Low vitamin D levels predict stroke in patients referred to coronary angiography. Stroke 2008;39(9):2611-3.

71. Stojanovic OI, Lazovic M, Lazovic M, et al. Association between atherosclerosis and osteoporosis, the role of vitamin D. Arch Med Sci 2011;7(2):179-8.

72. Clemens TL, Adams JS, Henderson SL, et al. Increased skin pigment reduces the capacity of skin to synthesise vitamin D3. Lancet 1 1982;1(8263):74-6.

73. Blum M, Dolnikowski G, Seyoum E, et al.Vitamin D(3) in fat tissue. Endocrine 2008;33(1):90-4.

74. Wang TJ, Zhang F, Richards JB, et al. Common genetic determinants of vitamin D insufficiency: a genome-wide association study. Lancet 2010;376(9736):180-8.

75. Thygesen K, Alpert JS, White HD, et al. Universal definition of myocardial infarction. Circulation 2007;116(22):263453. 